\title{
Rikkakasvien torjunta kasviperäisillä yhdisteillä
}

\author{
Sirkka Jaakkola ${ }^{1)}$ ja Marjo Keskitalo ${ }^{2)}$ \\ ${ }^{1)}$ MTT, Kasvintuotannon tutkimus, Kasvinsuojelu, 31600 Jokioinen, sirkka.jaakkola@mtt.fi \\ ${ }^{2)}$ MTT, Kasvinviljely ja biotekniikka, 31600 Jokioinen, marjo.keskitalo@mtt.fi
}

\section{Johdanto}

Monet kasvit tuottavat myrkyllisiä sekundääriaineita, joilla ne puolustautuvat tuholaisia, taudinaiheuttajia ja toisia kasveja vastaan. Kuminan siemenet sisältävät 2,5-8 \% kuiva-aineesta haihtuvaa öljyä, pääasiassa terpeenejä karvonia, limoneenia ja karveolia (Keskitalo et al. 2000). Kuminaöljyn terpeenit ovat estäneet mm. joidenkin tuholaisten kehitystä (Viglierchio and Wu 1989) ja perunoiden itämistä (Reust 2000). Kuminaöljy on laboratoriokokeissa estänyt kokonaan perunaruton kasvun ja kenttäkokeissa viivästyttänyt sen leviämistä parilla viikolla (Hannukkala et al. 2002). Myös tillin siemenissä on limoneeni- ja karvonipitoista haihtuvaa öljyä 2-4 \% (Hälvä 1986). Sinapin siemenissä puolestaan on runsaasti glukosinolaatteja, joiden hajotessa entsymaattisesti syntyy siementen itämistä ja taimien kasvua haittaavia yhdisteitä (Brown and Morra 1997). Näillä kasviperäisillä aineilla saattaisi olla potentiaalia rikkakasvien torjunnassa.

Tutkimuksen tavoitteena oli selvittää, voidaanko kasviperäisillä yhdisteillä, erityisesti haihtuvilla kumina- ja tilliöljyillä estää yksivuotisten rikkakasvien kasvua. Lisäksi haluttiin selvittää ruiskutusajankohdan ja öljyn eristysmenetelmän vaikutusta rikkakasvitehoon. Kokeisiin otettiin mukaan myös sinappipuriste, jolla aiemmin oli saatu rohkaisevia tuloksia.

\section{Aineisto ja menetelmät}

Öljyt eristettiin puristamalla ja tislaamalla. Sinapin siemenistä puristettiin öljy ja puriste jauhettiin ennen levitystä. Aineita testattiin sekä kasvihuoneessa että eurajokelaisella herneviljelmällä.

Kasvihuonekokeessa tilli- ja kuminaöljyn väkevyydet olivat 2,5\%, 5,0 \%, $10 \%$ ja $20 \%$. Testikasvina oli saunakukka, joka ruiskutettiin joko 5-6-lehtiasteella, 2-3-lehtiasteella tai sirkkalehtiasteella. Kontrollina oli ruiskutus vedellä. Saunakukat koulittiin taimettumisen jälkeen litran vetoisiin ruukkuihin. Koemenetelmä oli osaruutukoe, jossa pääruutuna oli ruiskute ja osaruutuna ruiskutusajankohta. Jokaista käsittelyä vastasi yksi ruukku. Kerranteita oli viisi, paitsi sirkkalehtiasteen käsittelyissä vain kaksi. Ruiskutuksen jälkeen arvioitiin taimien vioitukset ja kokeen päättyessä punnittiin taimien tuorepainot.

Aineita testattiin myös herneviljelmällä kesällä 2001. Puristettu kumina- ja tilliöljy ruiskutettiin rikkakasvien lehdille $5 \%$ ja $10 \%$ liuoksina ja tislattu kuminaöljy 7,5\% liuoksena. Kontrolli ruiskutettiin vedellä. Jauhemaiset kelta- ja sareptansinapin siemenpuristeet sekoitettiin herneen riviväleihin 50, 100, 150 ja $200 \mathrm{~g} \mathrm{~m}^{-2}$. Kontrollissa pintamaa sekoitettiin kevyesti, kuten Koemenetelmänä oli lohkoittain satunnaistettujen ruutujen menetelmä ja kerranteita neljä. Ruudun ala oli $6 \mathrm{~m}^{-2}$. Käsittelyjen aikaan herneen taimet olivat noin $5 \mathrm{~cm}: n$ pituisia. Käsittelyjen jälkeen herneen vioitukset arvioitiin visuaalisesti. Rikkakasvinäytteet ja sato korjattiin kokeen lopussa kustakin ruudusta $0,50 \mathrm{~m}^{-2}$ alalta. Aineistojen tilastokäsittelyt tehtiin varianssianalyysilla käyttäen SAS:sin Mixed Models-ohjelmaa. Keskiarvojen erojen vertailuun käytettiin Tukeyn t-testiä.

\section{Tulokset ja tulosten tarkastelu}

Kuminaöljyn eristysmenetelmä vaikutti aineen tehoon rikkakasveja vastaan. Vain tislattu, väkevä kuminaöljy haittasi saunakukan kasvua kasvihuonekokeessa (Taulukko 1). Saunakukat olivat sirkkalehtiasteella arimmillaan. Ruiskutus $20 \%$ tislatulla kuminaöljyllä vioitti $20 \%$ saunakukkien lehtialasta niiden ollessa 2-3- ja 5-6-lehtiasteella. Oireet näkyivät lehtien kellastumisena ja kuivumisena. Isot taimet toipuivat ennalleen, sirkkataimet sen sijaan kuolivat ruiskutuksen jälkeen.Tislauksen avulla saadaan puhtainta, $100 \%$ :sta öljyä, jossa on pelkästään karvoni- ja limoneeniterpeenejä. Puristamalla tuotettu öljy sisältää terpeenien lisäksi muita siemenen sisältämiä komponentteja.

Peltokokeessa ainoastaan tislattu kuminäljy ja kelta- ja sareptansinapin suurimmat annokset haittasivat pellon yleisimpien rikkakasvien, jauhosavikan ja pihatähtimön taimettumista ja kasvua tilastollisesti merkitsevästi (Kuva 1). Herne osoittautui erittäin alttiiksi tislatulle kuminaöljylle ja keltasinappipuristeelle. Öljy aiheutti lehtiin polttovioituksia ja keltasinappipuriste kellastutti lehdet vähitellen oireiden edetessä alhaalta ylöspäin. Vioitukset hidastivat herneen kasvua, mikä näkyi myös 
heikkona satona. Parhaat sadot saatiin vedellä tai mäntysuovalla terästetyllä vedellä ruiskutetuista ruuduista ja heikoin sato ruuduilta, joihin oli levitetty suurin keltasinappiannos (Taulukko 2.). Kuivan kevään takia suuri osa rikkakasveista taimettui vasta ruiskutuksen jälkeen, mikä vaikutti osaltaan kasviöljyjen heikkoon tulokseen. Sinapeista vapautuvien aineiden tiedetään menettävän tehoaan kuivuuden vuoksi (Matthiessen and Kirkegaard 2002). Kokeet osoittivat, että tislatussa kuminaöljyssä ja keltasinappipuristeessa on voimakkaasti toisiin kasveihin vaikuttavia yhdisteitä, mutta niiden hyödyntäminen vaatii lisätietoja mm. valikoivuudesta ja muista tehoon vaikuttavista tekijöistä.

Taulukko 1. Kasviöljyruiskutuksen vaikutus saunakukan kasvuun.

\begin{tabular}{|lccc|}
\hline Käsittely & \multicolumn{3}{c|}{ Taimien suhteellinen paino } \\
& 5-6-lehtiaste & 2-3-lehtiaste & sirkkalehtiaste \\
\hline Käsittelemätön & 100 & 100 & 100 \\
Mäntysuopa 2,5 \% & 120 & 98 & 95 \\
Kuminaöljy, puristettu 2,5\% & 117 & 89 & 120 \\
Kuminaöljy, puristettu 5\% & 95 & 94 & 200 \\
Kuminaöljy, puristettu 10 \% & 112 & 87 & 255 \\
Kuminaöljy, puristettu 20 \% & 105 & 93 & 160 \\
Kuminaöljy, tislattu 2,5 \% & 113 & 94 & 170 \\
Kuminaöljy, tislattu 5 \% & 116 & 109 & 123 \\
Kuminaöljy, tislattu 10\% & 118 & 83 & 30 \\
Kuminaöljy, tislattu 20 \% & 68 & 61 & 0 \\
Tilliöljy, puristettu 2,5 \% & 114 & 80 & 155 \\
Tilliöljy, puristettu 5 \% & 108 & 86 & 75 \\
Tilliöljy, puristettu 10 \% & 112 & 87 & 105 \\
Tilliöljy, puristettu 20 \% & 115 & 109 & 35 \\
& & & \\
\hline
\end{tabular}

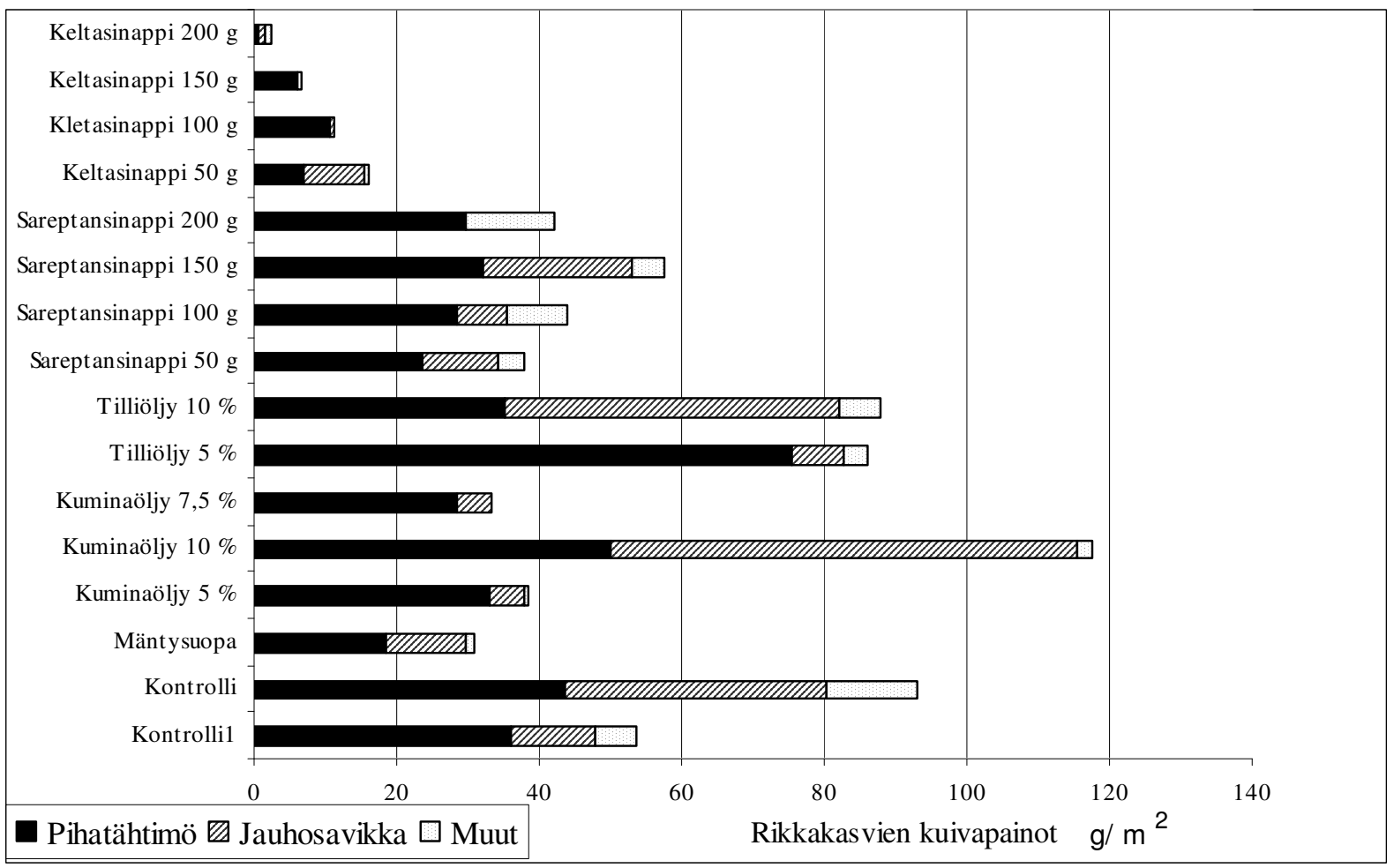


Kuva 1. Kasviöljyjen ja sinappipuristeiden vaikutus herneen rikkakasveihin. Kontrolli on käsitelty vedellä. Kontrolli1:ssä pintamaa on sekoitettu kuten siemenpuristelevityksessä.

Taulukko 2. Kasviöljyjen ja sinappipuristeiden vaikutus herneen satoon.

\begin{tabular}{|ll|}
\hline & $\begin{array}{l}\text { Herneen sato, \% } \\
\text { käsittelemättömästä }\end{array}$ \\
\hline Kontrolli, vesi & 100 \\
Kontrolli, haraus & 92 \\
Mäntysuopa 2,5 \% & 101 \\
Kuminaöljy, puristettu 2,5\% & 93 \\
Kuminaöljy, puristettu $10 \%$ & 97 \\
Kuminaöljy, tislattu 7,5 \% & 82 \\
Tilliöljy, puristettu $5 \%$ & 99 \\
Tilliöljy, puristettu $10 \%$ & 100 \\
Sareptansinappi $50 \mathrm{~g} \mathrm{~m}^{-2}$ & 79 \\
Sareptansinappi $100 \mathrm{~g} \mathrm{~m}^{-2}$ & 80 \\
Sareptansinappi $150 \mathrm{~g} \mathrm{~m}^{-2}$ & 71 \\
Sareptansinappi $200 \mathrm{~g} \mathrm{~m}^{-2}$ & $67 *$ \\
Keltasinappi $50 \mathrm{~g} \mathrm{~m}^{-2}$ & 78 \\
Keltasinappi $100 \mathrm{~g} \mathrm{~m}^{-2}$ & 71 \\
Keltasinappi $150 \mathrm{~g} \mathrm{~m}^{-2}$ & $67 *$ \\
Keltasinappi $200 \mathrm{~g} \mathrm{~m}^{-2}$ & $49 *$ \\
\hline
\end{tabular}

$*(\mathrm{P}<0,05)$ Keskiarvo eroaa merkitsevästi harauskontrollista, jossa pintamaa on sekoitettu kuten siemenpuristelevityksessä.

\section{Johtopäätökset}

Tislattu, väkevä kuminaöljy ja suurimmat (150-200 $\mathrm{g} \mathrm{m}^{-2}$ ) keltasinappipuristemäärät estivät yksivuotisia rikkakasveja taimettumasta ja haittasivat tainten kasvua, mutta samalla vioittivat voimakkaasti viljelykasvina ollutta hernettä. Kuminaöljyn vioituksia voidaan välttää ruiskuttamalla rikkakasvit ennen viljelykasvin taimettumista. Jatkossa tulisikin testata kuminaöljyn tehoa tilanteissa, joissa rikkakasveja on taimettunut runsaasti ennen viljelykasvin taimettumista. Sinappipuriste soveltuu parhaiten rikkakasvien torjuntaan leveistä riviväleistä silloin, kun maa on kosteaa. Aineet ovat mielenkiintoisia vaihtoehtoja puutarhakasvien rikkakasvien torjuntaan, mutta edellyttävät tutkimuksia viljelykasvien arkuudesta ja aineiden tehosta eri rikkakasveihin.

\section{Kirjallisuus}

Brown, P. D. \& Morra, M. J. 1997. Control of soil-borne plant pests using glucosinolate-containing plants. Advances in Agronomy 61: 167-231.

Hannukkala, A., Keskitalo, M., Laamanen, J., Rastas, M. 2002. Control of potato late blight with Caraway and Dill extracts . In: H.T.A.M. Schepers and C.E. Westerdijk, editors. Proceedings of the sixth workshop of an European network for development of an integrated control strategy of potato late blight.Edingburgh, Scotland, 26-30 September 2001. PPO-special report 8: 279-280. (posteriabstrakti).

Hälvä, S. 1986. Mausteita omasta maasta. Kirjayhtymä. Helsinki. 117 s.

Keskitalo, M., Linnala, M. \& Pihlava, J.-M. 2000. Production of plant biomolecules for food in nordic growth conditions. IN: European Conference on Nutritional Enhancement of Plant Foods: Neodiet; Norwich Research Park, September 2000. 1 p.

Matthiessen, J. \& Kirkegaard, J. 2002. Biofumication with brassicas. Fruit \& Veg Tech 2: 28-31.

Reust, W. 2000. Carvone, a new natural sprouting inhibitor for potato storage. Revue Suisse d'Agriculture. 32 : 150-152.

Viglierchio, D. R. \& Wu, F. F. 1989. Selected biological inhibitors for Heterodera schachtii control. Nematropica 19: 75-79. 